\title{
Rainfall-driven Episodic Flood Events: are they a major factor in moulding New South Wales arid land vegetation patterns?
}

\author{
MARTIN E. WESTBROOKE \& SINGAREYER K. \\ FLORENTINE, University of Ballarat, Australia
}

\begin{abstract}
Episodic high rainfall has been proposed as an important factor in perennial species recruitment but flooding based on rainfall at a distance from the site has received little attention. Although such flood events in arid Australia are rare, studies of the ephemeral Olary Creek indicate that occasional floods can also have a high impact on the vegetation and landscape. During February 1997, a high-rainfall event caused flooding in the Olary Creek. One branch of the creek created a terminal lake within mallee vegetation on Nagaela Station in far-western New South Wales. The flood path of Olary Creek and this terminal lake allow study of the importance of rainfall-driven flood events in shaping vegetation in arid environments. This paper reports (i) the response of arid land plant species to high-rainfall-driven episodic flood events and (ii) how grazing pressure from native and introduced herbivores can impact on native species response.

A systematic study was conducted to understand the botanical composition in flooded and control areas based on $25 \mathrm{~m}^{2}$ fenced and unfenced plots subjected to flooding and nonflooding. For 6 years following flooding, species richness in the flooded area was twice that of unflooded areas. In particular, 27 native species from 13 families were recorded both in the enclosed and open plots located in the flooded area. Over the study period nine species: Brachyscome ciliaris, Helichrysum leucopsidium, Vittadinia cuneata, Casuarina pauper, Maireana sedifolia, Salsola kali, Sclerolaena obliquicuspis, Eremophila sturtii and Eucalyptus foecunda germinated only in the flooded enclosed plots. Further, 11 exotic species from five families were recorded in the flooded (both enclosed and open) plots over the study period. Knowledge gained from this study will contribute to management strategies for arid land vegetation.
\end{abstract}

KEY WORDS Flooding; regeneration; arid landscape; mallee; New South Wales.

\section{Introduction}

There is a widely held view that Australian arid zone vegetation is shaped by erratically occurring high-rainfall events (Stafford-Smith \& Morton 1990). Such events are critical in triggering regeneration of long-lived perennials (Griffin \& Friedel 1985). As noted by Lange and Graham (1983), an essential factor is the co- 
occurrence of low-probability high-rainfall events, follow-up rains and low grazing levels. Noble (1986) considered the chances of these events occurring in different situations and determined that only on roadsides was there any real probability of these conditions co-occurring. Even on roadsides he estimated the chance as 1 in 250 years. Further, Westoby (1980) has noted that the response of plants to high-rainfall events differed according to life-form. Rare floods in the Olary Creek in 1989 and 1997 demonstrate that large flows of water across arid landscapes (see Figure 1) also have a major influence on landscape and vegetation structure.

Whilst fire, drought and grazing have been the subject of considerable research, little is known of the impact of flooding in arid environments and its interaction with other factors. These sporadic events may have played a major role in determining Australian arid-zone vegetation. Watson et al. (1997a, b) studied the continuous episodic components of demographic change in arid shrubs and also the demography of two shrub species from an arid grazed ecosystem. They concluded that shrub population dynamics was driven by continuous processes and episodes. In order to manage arid vegetation and to predict how arid species respond to such rare events, information and knowledge on such systems are required. Previous studies have focused on the impacts of grazing and rainfall on arid vegetation, but the interaction of flooding and grazing on changes in botanical composition, and how plants respond to these events, has received little attention. Following changes in weather patterns, these events could become more frequent. In this context, the floods that have occurred in Olary Creek, South Australia and New South Wales provide a valuable opportunity for studying the impact of major

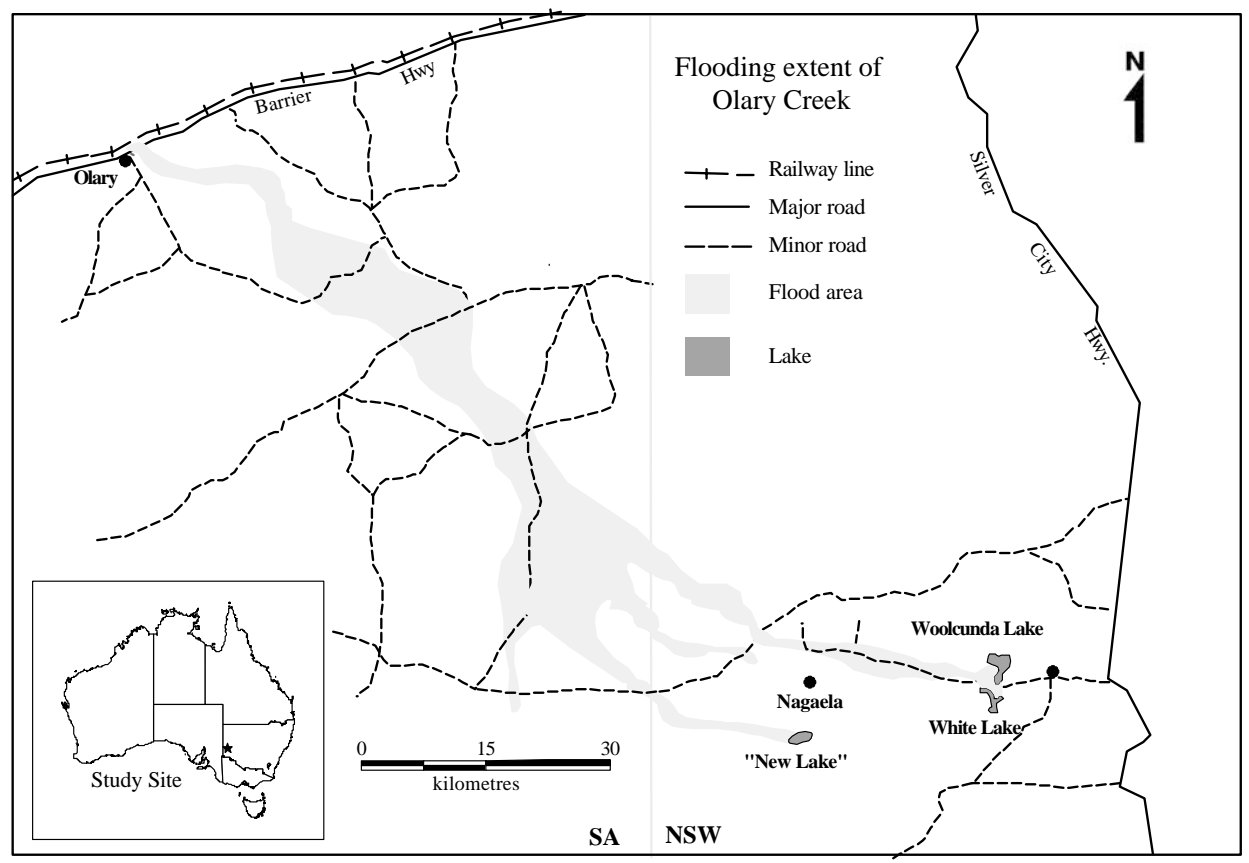

FIGURE 1. Location of the Olary Creek. 
flood events on arid ecosystem structure and function, and patterns of species colonisation.

The 1997 flow in the southern channel of Olary Creek washed through an area of mallee vegetation before forming a lake within Nagalea Station. It is suggested that this last section is an original creek line that has not flowed to this extent for well over 100 years, allowing the drift of sand and establishment of mallee vegetation. Analysis of rainfall records from Olary and Mannahill, both adjacent to the main catchment of the Olary Creek (Clewett et al. 2003), indicate the potential for flood events in 1921, 1950, 1989 and 1997. Rainfall data for February/March of those years compared with the long-term average, along with noted or reported events, are presented in Table 1.

Assessment of Myoporum platycarpum regeneration along the creekline showed a correlation with past flood events (Westbrooke 1998). Following the 1997 flood, plant response was monitored from flooded and unflooded areas, within and outside grazing exclusion plots established around the Nagaela Lake. This paper reports (i) the response of arid land plant species to high-rainfall-driven episodic flood events and (ii) how grazing pressure from native and introduced herbivores can impact on native species response.

\section{Methods and study area}

The study area is within the catchment of the ephemeral Olary Creek, where the vegetation is comprised of mallee open-scrub (Westbrooke et al. 1998). Such vegetation has a sparse canopy of multi-stemmed eucalypts. The ephemeral Olary Creek rises in the Olary Ranges of northeast South Australia and flows south and east through Mutaroo and Oakvale Stations. There, one branch forms a large lake adjacent to Oakvale Homestead, while another splits into three channels that flow across the New South Wales border into Kimberley and Loch Lilly Stations. Two of these later join and flow due east to fill Woolcunda Lake, White Lake, and a new lake (Border Lake) within mallee vegetation on the NSW/SA border. The third

TABLE 1. Monthly rainfall $(\mathrm{mm})$ and events causing flows in Olary Creek over the 100 year period

\begin{tabular}{|c|c|c|c|c|c|}
\hline \multirow[b]{2}{*}{ Year } & \multicolumn{2}{|c|}{ Olary } & \multicolumn{2}{|c|}{ Mannahill } & \multirow[b]{2}{*}{ Effects } \\
\hline & February & March & February & March & \\
\hline 70 year average & 25 & 18 & 21 & 15 & \\
\hline 1921 & a & $\mathrm{a}$ & 143 & 134 & $\begin{array}{l}\text { Flooding of Olary Creek; Woolcunda } \\
\text { and White Lake filled (R. Seccombe, } \\
\text { Woolcunda Station, pers. comm.) }\end{array}$ \\
\hline 1950 & 152 & 107 & 74 & 87 & $\begin{array}{l}\text { Presumed flow in upper sections of } \\
\text { Olary Creek }\end{array}$ \\
\hline 1989 & 0 & 214 & 0 & 171 & $\begin{array}{l}\text { Extensive flooding along Olary Creek; } \\
\text { Woolcunda Lake filled } \\
\text { (Weston \& Westbrooke 1999) }\end{array}$ \\
\hline 1997 & 216 & 0 & 271 & 0 & $\begin{array}{l}\text { Extensive flooding along Olary } \\
\text { Creek; Woolcunda and White Lake } \\
\text { filled (Weston \& Westbrooke 1999) }\end{array}$ \\
\hline
\end{tabular}

\footnotetext{
a Data not available.
} 
channel flows southeast into Nagaela Station to form a terminal lake within mallee vegetation (see Figure 1). The creek flowed for the first time in many years in February 1989 (K. Weitch, Oakvale Station, pers. comm.), and again more extensively in February 1997, after up to $216 \mathrm{~mm}$ rainfall fell in 24 hours (close to mean annual rainfall). This rare flood event caused severe erosion and also formed ephemeral lakes within Oakvale and Nagaela Stations after washing through mallee vegetation. The water level in the newly created Nagaela Lake was up to $2 \mathrm{~m}$ at the deepest point. The water stayed for approximately 2 years. Weston and Westbrooke (1999) have suggested that the water flooded an original creek line that had not flowed to this extent for more than 100 years, allowing the drift of sand and establishment of mallee vegetation. Rainfall records and reports from Olary and Mannahill suggest four flooding events since the 1920s (see Table 1). Prior to the September 1997 flooding event, part of the vegetation around Olary Creek had been burnt by natural fire. Major vertebrate herbivores in the Olary Creek catchment are kangaroos, goats, sheep and rabbits. Mean monthly rainfall recorded at Tarawi Station is shown in Figure 2.

\section{Sequential events}

A rare flooding event occurred in February 1997. In February 1999, approximately 24 months after flooding (floodwater stayed approximately 21 months), plots were established in the flooded and non-flooded (control) area as the lake dried. Detailed vegetation data were collected in September 1999 (3 years and 10 months after the flood event), October 2002 (5 years and 10 months after the flood event) and October 2003 (6 years and 10 months after the flood event).

\section{Experimental design}

To assess the impact of this rare high-rainfall-driven flood, and grazing, $25 \mathrm{~m} \times 25$ $\mathrm{m}$ permanent plots were established in the 'new lake' in February 1999, 22 months after the flooding (February 1997) in control $(n=2)$ and flooded $(n=4)$ areas. The permanently marked plots were placed in pairs, with one of the plots in the pair left unfenced and the other fenced to exclude kangaroos, sheep, feral goats and rabbits.

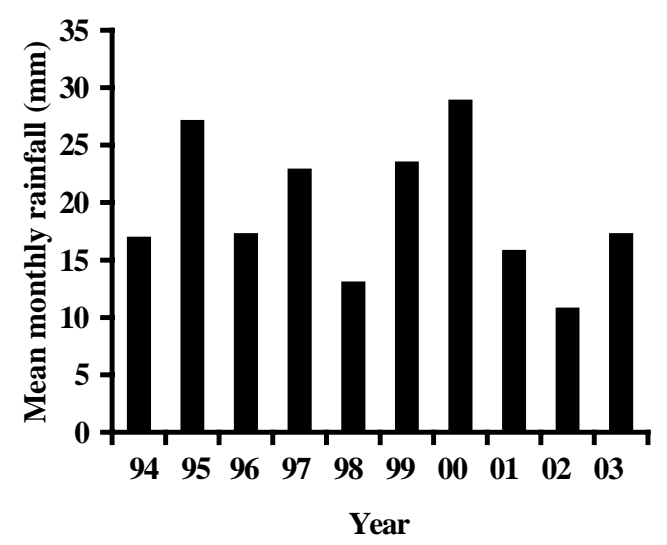

Figure 2. Mean monthly rainfall (mm) at Tarawi Station, from 1994 to 2003. 
Recruitment of overstorey species

Based on stem diameter data from 215, $50 \mathrm{~m} \times 50 \mathrm{~m}$ quadrates, coupled with growth-ring analysis, Westbrooke (1998) studied perennial species regeneration in Casuariana pauper woodlands. At most sites recruitment only occurred following several years of above-average rainfall.

\section{Results}

Species colonisation after the 1997 flooding event

Botanical composition and life-forms were recorded in $25 \mathrm{~m}^{2}$ fenced and unfenced plots subjected to flooding $(n=4)$ and non-flooding $(n=2)$. Species recorded, life-form, family, and whether native or exotic are given in Table 2. Table 3 presents pooled summaries of data collected in October 2000, 2002 and 2003. These data show that species richness in the flooded area is twice that of non-flooded areas. In particular, 27 native species from 13 families were recorded both in the enclosed and open plots located in the flooded area. Of these, 29 per cent (eight species), namely Atriplex sp., Chenopodium melanocarpum, Einadia nutans, Enchylaena tomentose, Maireana sedifolia, Marieana radiata, Salsola kali, Sclerolaena obliquicuspis, were from the Chenopodiaceae and 18 per cent (five species), namely Angianthus pusillus, Brachyscome ciliaris, Pseudognaphalium luteo-album var. incanum, Helichrysum leucopsidium and Vittadinia cuneata, were from the Asteraceae. Other species included Daucus glochidiatus (Apiaceae), Herniaria hirsuta (Caryophyllaceae), Lomandra leucocephala ssp. robusta (Dasypogonaceae), Poranthera microphylla (Euphorbiaceae), Erodium malacoides (Geraniaceae), Acacia burkittii and A. colletioides (Mimosaceae), Eremophila sturtii (Myoporaceae), Eucalyptus foecunda (Myrtaceae), Eragrostis dielsii and Pennisetum villosum (Poaceae), Dodonaea viscosa (Sapindaceae), and Nicotiana velutina (Solanaceae).

Of the 27 species recorded, 13 (48 per cent) were annual herbs and grasses, seven (29 per cent) were perennial shrubs, four (14 per cent) were trees and two were tussock species.

Over the 4 years of study, nine species: Brachyscome ciliaris, Helichrysum leucopsidium, Vittadinia cuneata, Casuarina pauper, Marieana sedifolia, Salsola kali, Sclerolaena obliquicuspis, Eremophila sturtii and Eucalyptus foecunda were found growing only in the flooded enclosed plots.

Of particular note was a Casuarina pauper (Casuarinaceae) seedling recorded in the flooded enclosed plot. Though five grass species were recorded only in the flooded area, three of these were annual exotics. Of the native grasses, one, Pennisetum villosum, is an annual while Eragrostis dielsii is a perennial tussock species.

\section{Exotic invasion after 1997 flooding event}

Eleven exotic species from five families were recorded in the flooded (both enclosed and open) plots over the study period but in contrast no exotic species were recorded. Exotic species recorded in the flooded enclosed and open plots were: Dittrichia graveolens, Onopordum acanthium, Sonchus asper, Sonchus oleraceus (Asteraceae), Bromus rubens, Critesion murinum ssp. leporinum, Schismus barbatus 
TABLE 2. Species recorded in the flooded enclosure, open, non flooded (control) enclosure and open plots between the years 2000 and 2003

\begin{tabular}{|c|c|c|c|c|c|c|c|c|c|c|c|c|c|}
\hline \multirow[b]{2}{*}{ Species } & \multirow[b]{2}{*}{ Life-form } & \multicolumn{4}{|c|}{2000} & \multicolumn{4}{|c|}{2002} & \multicolumn{4}{|c|}{2003} \\
\hline & & $\mathrm{FO}$ & $\mathrm{CO}$ & $\mathrm{FE}$ & $\mathrm{CE}$ & $\mathrm{FO}$ & $\mathrm{CO}$ & $\mathrm{FE}$ & $\mathrm{CE}$ & $\mathrm{FO}$ & $\mathrm{CO}$ & $\mathrm{FE}$ & $\mathrm{CE}$ \\
\hline Olearia subspicata & Shrub & $\times$ & $\times$ & $\times$ & $\times$ & & & & & & & & \\
\hline Halgania cyanea & Shrub & $\times$ & $\times$ & $\times$ & $\times$ & & & & & $\times$ & & & \\
\hline Senna artemisioides ssp. petiolaris & Shrub & & & $\times$ & $\times$ & & & & $\times$ & & $\times$ & & \\
\hline Casuarina pauper & Tree & & & & & & & & & & & $\times$ & \\
\hline Atriplex sp. & Shrub & & & & & & & $\times$ & & $\times$ & & $\times$ & \\
\hline Chenopodium curvispicatum & Shrub & $\times$ & $\times$ & $\times$ & $\times$ & & & & & $\times$ & $\times$ & $\times$ & $\times$ \\
\hline Chenopodium desertorum & Shrub & & & $\times$ & $\times$ & & & $\times$ & & $\times$ & & $\times$ & \\
\hline Einadia nutans & Shrub & & & & & & & & & $\times$ & & & \\
\hline Enchylaena tomentos & Shrub & & & & & & & $\times$ & & $\times$ & & & \\
\hline Maireana georgei & Shrub & & & & & & & & & & & $\times$ & $\times$ \\
\hline Maireana pentatropis & Shrub & & & $\times$ & $\times$ & & & & $\times$ & & & $\times$ & \\
\hline Maireana sedifolia & Shrub & & & & & & & $\times$ & & $\times$ & & $\times$ & \\
\hline Maireana radiata & Shrub & & & & & & & & & & & $\times$ & \\
\hline Sclerolaena diacantha & Shrub & $\times$ & $\times$ & $\times$ & $\times$ & & & & & $\times$ & $\times$ & $\times$ & $\times$ \\
\hline Sclerolaena obliquicuspis & Shrub & & & $\times$ & & & & & & & & $\times$ & \\
\hline Sclerolaena parviflora & Shrub & $\times$ & $\times$ & $\times$ & $\times$ & & & $\times$ & & $\times$ & $\times$ & $\times$ & $\times$ \\
\hline Schoenus subaphyllus & Tussock & & & & & & & & & & & & $\times$ \\
\hline Lomandra effusa & Tussock & & $\times$ & $\times$ & $\times$ & & & & & & $\times$ & & $\times$ \\
\hline Lomandra leucocephala ssp. robusta & Tussock & $\times$ & & & & & & & & & & & \\
\hline Eutaxia microphylla var. microphylla & Shrub & & & $\times$ & $\times$ & & & & & & & & $\times$ \\
\hline Acacia aneura & Tree & & & $\times$ & $\times$ & & & & & & & & \\
\hline Acacia burkittii & Shrub & & & & & $\times$ & & $\times$ & & $\times$ & & $\times$ & \\
\hline Acacia colletioides & Tree & & & & & & & & & & & $\times$ & \\
\hline Acacia wilhelmiana & Shrub & & & $\times$ & & & & & & & & & $\times$ \\
\hline Eremophila glabra & Shrub & $\times$ & $\times$ & $\times$ & $\times$ & & & & $\times$ & & & & $\times$ \\
\hline Eremophila scoparia & Shrub & & & & & & & & & & & & $\times$ \\
\hline Eremophila sturtii & Shrub & & & & & & & $\times$ & & & & & \\
\hline Bromus rubens $\mathrm{L}$. & Grass & & & & & & & & & $\times$ & & $\times$ & \\
\hline Critesion murinum ssp. leporinum & Grass & & & $\times$ & & & & & & & & $\times$ & \\
\hline Eragrostis dielsii & Grass & $\times$ & & $\times$ & & $\times$ & & $\times$ & & $\times$ & & $\times$ & \\
\hline Pennisetum villosum & Grass & & & & & & & & & $\times$ & & & \\
\hline Schismus barbatus & Grass & & & & & & & & & $\times$ & & $\times$ & \\
\hline Stipa sp. & Tussock & $\times$ & $\times$ & $\times$ & $\times$ & $\times$ & & $\times$ & $\times$ & $\times$ & & $\times$ & \\
\hline Triodia scariosa ssp. scariosa & Tussock & $\times$ & $\times$ & $\times$ & $\times$ & $\times$ & $\times$ & $\times$ & $\times$ & & $\times$ & & $\times$ \\
\hline Calandrinia eremaea & Herb & $\times$ & & $\times$ & $\times$ & & & & & $\times$ & $\times$ & $\times$ & \\
\hline Grevillea huegelii & Shrub & & & & & & $\times$ & & $\times$ & & $\times$ & & $\times$ \\
\hline Dodonaea viscosa & Shrub & & & & & & & $\times$ & & $\times$ & & $\times$ & \\
\hline Duboisia hopwoodii & Shrub & $\times$ & $\times$ & $\times$ & $\times$ & & & & & & & & \\
\hline Nicotiana glauca Graham & Shrub & $\times$ & & $\times$ & & $\times$ & & $\times$ & & $\times$ & & $\times$ & \\
\hline
\end{tabular}

Notes:

$\mathrm{FO}=$ flooded open, $\mathrm{CO}=$ control open, $\mathrm{FE}=$ flooded enclosed, and $\mathrm{CE}=$ control enclosed. $\times=$ species present.

(Poaceae), Spergularia rubra (Caryophyllaceae), Brassica tournefortii (Brassicaceae), Salvia verbenaca (Laminaceae), and Nicotiana glauca (Solanaceae). Ten of these are herbs or annual grasses but the one perennial, the South American shrub N. glauca, invaded a large part of the lake and extended into the surrounding mallee 
TABLE 3. Summary of last 3 years' data on species recorded in the flooded and control plots

\begin{tabular}{lrrrr}
\hline & \multicolumn{3}{c}{ Treatment } \\
\cline { 2 - 5 } Parameters & \multicolumn{1}{c}{ FO } & FE & CO & CE \\
\hline Families & \multicolumn{1}{c}{ F } & 26 & 15 & 21 \\
Species & 45 & 69 & 27 & 39 \\
Annuals & 21 & 25 & 6 & 10 \\
Perennials & 24 & 44 & 21 & 29 \\
Native species & 38 & 59 & 27 & 39 \\
Exotic species & 7 & 10 & 0 & 0 \\
Life forms & $3(2)$ & $3(3)$ & $0(0)$ & $0(0)$ \\
$\quad$ Annual grasses & $1(0)$ & $1(0)$ & $0(0)$ & $0(0)$ \\
Perennial grasses & $3(0)$ & $3(0)$ & $3(0)$ & $3(0)$ \\
Tussocks & $18(4)$ & $24(7)$ & $6(0)$ & $10(0)$ \\
Annual herbs & $2(0)$ & $6(0)$ & $0(0)$ & $2(0)$ \\
Perennial herbs & $13(1)$ & $19(1)$ & $9(0)$ & $14(0)$ \\
Shrubs & $1(0)$ & $1(0)$ & $1(0)$ & $1(0)$ \\
Geophytes & $4(0)$ & $12(0)$ & $8(0)$ & $9(0)$ \\
Trees & & & & \\
\hline
\end{tabular}

Notes:

$\mathrm{FO}=$ flooded open, $\mathrm{FE}=$ flooded enclosed, $\mathrm{CO}=$ control open, and $\mathrm{CE}=$ control enclosed.

Numbers within parentheses represent the number of exotics.

shrubland. Nicotiana glauca density varied between flooded fenced and unfenced plots and also varied between assessments.

The lake on Nagaela Station created an island of approximately 4 ha, which remained isolated for 2 years. Under the conditions of high soil moisture, large numbers of mallee (Eucalyptus dumosa/E. socialis) eucalypt seedlings emerged which, in the absence of vertebrate grazing pressure, were able to establish. In spring 2001 these were at a density of 50000 seedlings/ha. In spring 2003 they still persisted at reduced densities but, following the total drying of the lake, were showing signs of grazing pressure from feral goats which are abundant in the area.

\section{Perennial overstorey recruitment}

Previous studies of arid woodland regeneration (Westbrooke 1998) have shown unusual regeneration characteristics in an area of open woodland dominated by M. platycarpum in the vicinity of New Dam on Loch Lilly Station (lat. $33^{\circ} 01^{\prime} 00^{\prime}$ long. $141^{\circ} 08^{\prime} 10^{\prime}$ ). The area has a range of age classes present despite being close to a reliable ground-water tank and apparently being subject to high grazing pressure (see Figure 3). Stem diameters suggest a number of regeneration events over the past 100 years, not solely explained by rainfall events in the area.

It has previously been demonstrated that $M$. platycarpum has clear annual growth rings (Westbrooke 1998). Sections were cut from stems from a cohort of trees growing close to a ground tank where high grazing pressure would be expected. Ring analysis suggested an age of 80 years, coinciding with the 1921 flood event. Extensive regeneration of $M$. platycarpum was also observed along the creek following the 1997 flood. 


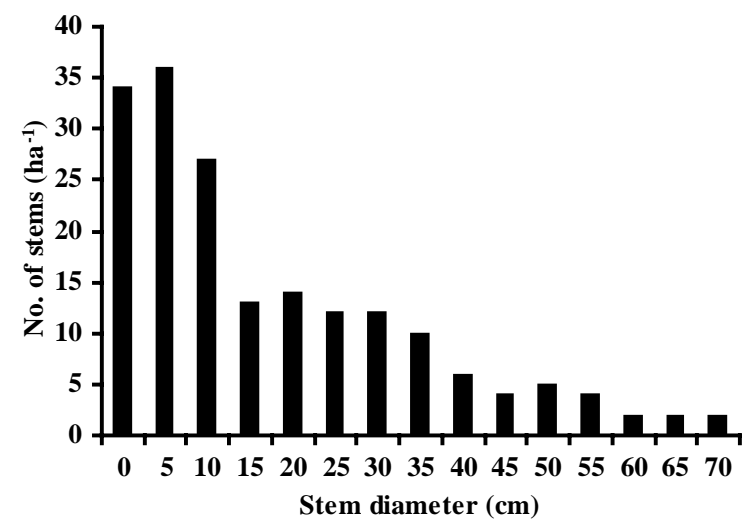

FIGURE 3. Myoporum platycarpum seedlings recorded in September 1997 adjacent to the Olary Creek floodline on Loch Lilly Station.

Within Oakvale Station Olary Creek flows through areas of Belah woodland and, along the line of the creek, tree densities are far higher than in surrounding areas. Westbrooke (1998) has linked growth rings to past flood events.

\section{Discussion}

\section{Post-flood species colonisation}

As noted previously, most studies on arid land botanical composition and their irruption patterns have focused on normal rainfall. It is well known that annual plant species respond strongly to annual variation in rainfall (Bowers 1987; Gutierrez \& Whitford 1987; Aronson \& Shmida 1992; Hobbs \& Mooney 1995; Guo \& Brown 1996; Milton \& Dean 2000). How botanical composition responds to high-rainfall-driven flood events, however, has received little attention, mainly because such high-rainfall-driven flood events have been ignored as 'once in a lifetime'. Further, Sala and Lauenroth $(1982,1985)$ have demonstrated that even rainfall events of $5 \mathrm{~mm}$ or less can play a vital role in shaping arid land botanical composition. Therefore, it is essential to evaluate the importance of rainfall-driven flood events in shaping vegetation in arid environments. The knowledge gained from this study will place us in a better position to manage arid lands.

In the present study, we compared botanical composition of flooded areas (open and enclosed) with non-flooded (open and enclosed) areas following a rare highrainfall-driven episodic flood event. Our study documented the diverse range of species and life-forms, both native and exotic, that irrupted after a rare flooding event. Results show that the number of species recruited in flooded areas where grazing was excluded was twice that of non-flooded plots. As found previously, plant functional attributes are reliable indicators of climatic changes (Friedel et al. 1988; Grime et al. 1988; Noy-Meir et al. 1989; Leishman \& Westoby 1992). Twenty-seven native species from 13 families were recorded both in the enclosed and open plots located in the flooded area. In particular, perennial grass and perennial shrubs were influenced by this rare flooding event. Exclusion studies showed that grazing from native and introduced vertebrate animals had a high impact on perennial species composition. 
It is important to look at the plant response to the 1997 flooding event in the context of the theory of water availability effects on arid land plant species. It could be argued that both annual and perennial species vary temporally and spatially and the difference observed in plant functional attributes may be misleading. As discussed above, annuals respond positively to even small amounts of sporadic summer rainfall in arid lands (Florentine 1999). Similarly, Henschel and Seely (2000) have noted that irruption of long-lived species is confined to rare occasions when soil water reservoirs are substantial enough to allow the taproot of newly recruited seedlings to access soil depths with a continuous supply of water. Our study shows not only that large number of annuals irrupted in response to this rainfall but also that perennial species respond more positively in the flooded plots than non-flooded plots. Thus, based on previous findings, we suggest that high perennial recruitment reflects the 1997 flooding event.

Recruitment of annual species after rainfall events is a common phenomenon (Friedel et al. 1988; Grime et al. 1988). This is reflected in this study, where 44 per cent of species recorded were annuals. However, results show that perennial shrubs and grasses are also able to regenerate as a result of flooding. Additionally, the flood enabled the invasion of a number of exotic species. The overall result is a significant change in native vegetation composition and structure.

\section{Exotic invasion}

The rare episodic flooding event (1997) not only facilitated native annual and perennial species recruitment but also brought exotic plant species into this newly created lake. One exotic species, N. glauca, is a major concern. Forward and Robinson (1996) conducted a biological survey of the south Olary plains which provides botanical composition and landform data for the South Australian component of the study area. In that botanical survey no N. glauca was recorded.

Westbrooke et al. (2005) and Florentine and Westbrooke (2005) found that this species was prominent in flooded areas but absent in non-flooded areas. Larger numbers of $N$. glauca were found in the long-term flood zone than the short-term flood zone. The authors have suggested that the variation in N. glauca density confirms that this species establishes itself in high soil moisture areas. It is believed that the high-rainfall event, resulting in flooding sufficient to leave standing water for several months, created ideal conditions for the establishment of $N$. glauca. Seeds of $N$. glauca are likely to have been brought from upstream and collected in the newly formed terminal lake. As flooded areas dried out, $N$. glauca seed deposited on peripheral mud (short-term flood zone) germinated and formed a dense stand (Florentine \& Westbrooke 2005). Nicotiana glauca is a fast-growing tree, particularly after good rainfall events, and produces flowers approximately 1 year after germination (Boyland et al. 1985). Nicotiana glauca trees in the shortterm flood zone are likely to have supplied seeds to the long-term flood zone. This is supported by the population structure of $N$. glauca, which shows that large numbers of trees in the larger height and diameter class were found only in the short-term flood zone.

Higher numbers of exotic species in the unfenced plots as compared with the fenced plots may be due to grazing pressure from goats, kangaroos and rabbits. This high grazing pressure may have eliminated competition from native shrubs and grass species, creating ideal conditions for $N$. glauca seedlings to utilise 
available resources such as water and space to establish and survive during the subsequent summer months.

\section{Conclusion}

In conclusion, these rare flooding events have created suitable conditions for annuals and, more importantly, long-lived perennial species. As Florentine and Westbrooke (2005) have pointed out, $N$. glauca is potentially a serious weed in arid catchments such as Olary Creek. Our study suggests that $N$. glauca tree density is higher in the open flooded plots where grazing has eliminated competition from pre-existing shrub and grass species. Native species are already being impacted by increased grazing pressure from native and exotic animals and drought. Invasion by weed species such as $N$. glauca may put further pressure on their survival. These data showing regeneration resulting from flows in Olary Creek indicate that, in localised situations, events may occur which permit regeneration other than at times when there are good rains over 3 years. This is further evidence of the importance of rare episodic flooding events in moulding local botanical composition. Such flooding events may occur at more or less frequent intervals in the future. The knowledge gained from this study would contribute to improved management strategies for arid land vegetation.

\section{Acknowledgements}

We are grateful for the support and assistance of pastoralists in the area, especially Joy and Keith Weitch of Oakvale Station, Randy Graham of Nagalea Station and Paul Gross of Loch Lilly Station. Thanks also to Marion O'Keefe for preparation of Figure 1 and to two anonymous referees who provided constructive comments on an earlier draft.

Correspondence: Singareyer K. Florentine, School of Science and Engineering, Centre for Environmental Management, University of Ballarat, PO Box 663, Victoria 3350, Australia. E-mail: s.florentine@ballarat.edu.au

\section{REFERENCES}

Aronson, J. \& Shmida, A. (1992) 'Plant species diversity along a Mediterranean desert gradient and its correlation with interannual rainfall fluctuations', fournal of Arid Environments 23, pp. 23547.

Bowers, M.A. (1987) 'Precipitation and the relative abundance of desert winter annuals: a 6 year study in the northern Mohave Desert', fournal of Arid Environments 12, pp. 14150.

Boyland, D.E., Carolin, R.C., George, A.S., Jessop, J.P. \& Maconochie, J.R. (eds) (1985) Flora of central Australia, Reed Books, Sydney.

Clewett, J.F., Smith, P.G., Partridge, D.A., George, D.A. \& Peacock, A. (2003) Australian Rainman: rainfall information for better management, Department of Primary Industries, Brisbane.

Florentine, S.K. (1999) 'Ecology of Eucalyptus victrix in grassland in the floodplain of the Fortescue River', unpublished $\mathrm{PhD}$ thesis, Curtin University of Technology, WA, Australia.

Florentine, S.K. \& Westbrooke, M.E. (2005) 'Invasion of the noxious weed Nicotiana glauca R. Graham after an episodic flooding event in the arid zone of Australia', Fournal of Arid Environments 6, pp. 53145. 
Forward, L.R. \& Robinson, A.C. (1996) A biological survey of the south Olary plains, South Australia, Department of Environment and Natural Resources, South Australia.

FrIEDEL, M.H., BASTIN, G.N. \& GRIFFIN, G.F. (1988) 'Range assessment and monitoring in arid lands: the derivation of functional groups to simplify data', Fournal of Environmental Management 27, pp. 8597.

GrIFFIN, G.F. \& FreIDEL, M.H. (1985) 'Discontinuous change in central Australia: some implications of major ecological events for land management', fournal of Arid Environments 9, pp. 6380.

Grime, J.P., Hodgson, J.G. \& Hunt, R. (1988) Comparative plant ecology. A functional approach to common British species, Unwin Hyman, London.

GuO, Q.F. \& BRown, J.H. (1996) 'Temporal fluctuations and experimental effects in desert communities', Oecologia 107, pp. 56877.

Gutierrez, J.R. \& Whitford, W.G. (1987) 'Responses of Chihuahuan Desert herbaceous annuals to rainfall augmentation', fournal of Arid Environments 12, pp. 12739.

HensChel, J.R. \& SEely, M.K. (2000) 'Long term growth patterns of Welwitschia mirabilis, a long lived plant of the Namib Desert (including a bibliography)', Plant Ecology 150, pp. 726.

HobBs, R.J. \& Mooney, H.A. (1995) 'Spatial and temporal variability in California annual grassland results from a long term study', fournal of Vegetation Science 6, pp. 4356.

LANGE, R.T. \& GRAHAM, C.R. (1983) 'Rabbits and the failure of regeneration in Australian arid zone Acacia', Australian fournal of Ecology 8, pp. 37782.

LeISHMAN, M.R. \& WESTOBY, M. (1992) 'Classifying plants into groups on the basis of associations of individual traits: evidence from the Australian semi arid woodlands', fournal of Ecology 80, pp. 41724.

Milton, S.J. \& DEAn, W.R.J. (2000) 'Disturbance, drought and dynamics of desert dune grassland, South Africa', Plant Ecology 150, pp. 3751.

Noble, I.R. (1986) 'The dynamics of range ecosystems', in Rangelands: a resource under siege, Proceedings of the Second International Rangeland Congress, Australian Academy of Science, Canberra.

Noy-Meir, I., GutMan, M. \& Kaplan, Y. (1989) 'Responses of vegetation to use by large herbivores: an assessment of some techniques', South African fournal of Wildlife Research 17, pp. 10917.

SALA, O.E. \& LAUENROTH, W.K. (1982) 'Small rainfall events: an ecological role in semiarid regions', Oecologia 53, pp. 3014.

SALA, O.E. \& LAUENROTH, W.K. (1985) 'Root profiles and the ecological effects of light rainshowers in arid and semiarid regions', American Midland Naturalist 114, pp. 4068.

STAFFORD-SMith, D.M. \& Morton, S.R. (1990) 'A framework for the ecology of arid Australia', Fournal of Arid Environments 18, pp. 25578.

Watson, I.W., Westoby, M. \& McR. Holm, A. (1997a) 'Demography of two shrub species from an arid grazed ecosystem in Western Australia, 1983 93', fournal of Ecology 85, pp. 81532.

Watson, I.W., Westoby, M. \& MCR. Holm, A. (1997b) 'Continuous and episodic components of demographic change in arid zone shrubs: models of two Eremophila species from Western Australia compared with published data on other species', fournal of Ecology 85, pp. 83346.

Westbrooke, M.E. (1998) 'The ecology and regeneration status of Belah woodland in south eastern Australia', unpublished $\mathrm{PhD}$ thesis, La Trobe University.

Westbrooke, M.E., Florentine, S.K. \& Milberg, P. (2005) 'Arid land vegetation dynamics after a rare flooding event: influence of fire and grazing', fournal of Arid Environments 61, pp. 24960.

Westbrooke, M.E., Miller, J.D. \& Kerr, M.K. (1998) 'Vegetation of the Scotia 1:100 000 mapsheet, far western New South Wales', Cunninghamia 5, pp. 66584.

Westoby, M. (1980) 'Elements of a theory of vegetation dynamics in aridlands', Israeli fournal of Botany 28, pp. 16994.

Weston, M. \& Westbrooke, M.E. (1999) 'The role of episodic events in moulding the vegetation of a part of western New South Wales', in People and rangelands building the future, Proceedings of the VIth International Rangeland Congress, VI Rangeland Congress Inc., Townsville, Australia, pp. 255 6. 